\title{
Recombinant protein expression and purification experiments based on SARS-CoV-2 Mpro
}

\author{
Jin Huang 1 \\ ${ }^{1}$ Academy of our lady of mercy-Lauralton Hall
}

\begin{abstract}
Mpro is one of the most important drug targets of the novel Coronavirus. In this study, a series of potential compounds were obtained through virtual drug screening targeting Mpro. Using the key protease (Mpro) of SARS-COV-2 as the drug lead target for virtual drug screening has become a hot topic in current virus research. Mpro plays a key role in virus replication and transcription. Therefore, the key experimental strain of Escherichia coli containing Mpro is commonly used to inhibit drugs from Mpro. In this study, Mpro gene was located on peT-28A vector, and the size of the recombinant protein was about $36 \mathrm{kDa}$. The e. Coli expression strain BL21(DE3) containing Mpro was inoculated and cultured.
\end{abstract}

\section{Introduction}

Mpro is one of the most important drug targets of novel Coronavirus, Since December 2019, Wuhan, Hubei Province has been continuously monitoring influenza and related diseases, and found a number of cases of viral pneumonia, all diagnosed as viral lung infection. The common signs of infection with coronavirus include respiratory symptoms, fever, cough, shortness of breath and dyspnea. In more severe cases, infection can lead to pneumonia, severe acute respiratory syndrome, kidney failure and even death. With regard to novel Coronavirus disease, many experts extracted the key protease (Mpro) of SARS-COV-2 as the drug lead target for virtual drug screening. This plays a key role in viral replication and transcription, making Mpro a drug target. In the offline experiment, I prepared a molecular docking software package developed by AutoDock for $\mathrm{C}$ language, which can complete molecular docking and result analysis in an almost completely graphical interface. Then, by preparing receptor molecules, Ligand molecules, macromolecules, and AutoGrid, Dock parameter files, and finally observing the connected molecular conformation and cluster conformation, and observing the connected conformation in the receptor environment, the preliminary virtual drug screening experiment was completed by computer. The drug virtual screening experiment was based on the recombinant expression and purification of SARS-COV-2 Mpro. In this experiment, the Mpro gene was located on the PET-28A vector, and the recombinant protein size was about $36 \mathrm{kDa}$. The escherichia coli expressing strain (BL21(DE3)) containing Mpro was inoculated and cultured.

\section{The structure and inhibitors of Mpro in SARS-COV-2}

\subsection{Relationship between Mpro and SARS}

The SARS-COV-2 genome contains many nucleotides: the sarS-COV-2 replicase gene encodes two overlapping polyproteins, PP1A and PP1AB, which are necessary for virus replication and transcription, and they are released from the polyproteins and released by the protease. [1] The source of SARS, Mpro, is a key enzyme that controls the activity of the coronavirus replication complex because its cleavage site is very similar to that of the PICornavirus 3C protease. It is this enzyme that is essential for the virus to replicate properly. [2]

\subsection{The discovery of inhibitors based on the Mpro}

In nature, Zhenming Jin, Xiaoyu Du, et al. wrote an article that had three similarities with the experimental process described in this paper. The first point is about sarS-COV-2 Mpro protein expression and purification, and the second point is about crystals grown in the buffer. [3]

\subsubsection{SARS-COV-2 Mpro protein expression and purification}

The full-length sarS-COV-2 Mpro (NC_045512) gene was synthesized and applied to the expression of Escherichia coli. The expression plasmid was transferred into Escherichia coli BL21 (DE3) cells and cultured in luria broth containing $100 \mathrm{MHZ} / \mathrm{mL}$ ampicillin at $37^{\circ} \mathrm{C}$. At $16^{\circ} \mathrm{C}$, when the cells grew to an optical density of $600 \mathrm{~nm} 0.6-0.8,0.5 \mathrm{~mm}$ IPTG was added to the cell culture

corresponding author's email address: jhuang22@lauraltonhall.org 
medium to induce expression. After $10 \mathrm{~h}$, the cells were collected by centrifugation at $3000 \mathrm{~g}$. The cell microspheres were resuspended in $20 \mathrm{~mm}$ Tris- $\mathrm{Hcl} \mathrm{pH} 8.0$ and $300 \mathrm{~mm} \mathrm{NaCl}$ lysis buffer. After a $25000 \mathrm{~g}$ centrifugation for 40 mins, the supernatant was installed on Qiagen ni-NTA affinity column and washed in $20 \mathrm{~mm}$ imidazole resuspended suspension. His labeled Mpro was eluted with a $300 \mathrm{mM}$ imidazole containing cleavage buffer $(50 \mathrm{mM}$ tris-Hcl $\mathrm{pH} 7.0,150 \mathrm{mM} \mathrm{NaCl})$. Add human rhinovirus $3 \mathrm{C}$ protease to remove the $\mathrm{C}$ end of His tag. Mpro was further purified by ion exchange chromatography and dimensional exclusion chromatography. Coronavirus Mpro was present in solution 33 as a mixture of monomers and dimers. The purified Mpro was stored in $50 \mathrm{mM}$ Tris- $\mathrm{HCl} \mathrm{pH}$ 7.3, 1
mM EDTA. [4]

\subsubsection{Crystals grown in a buffer}

In Nature, crystallization, data collection and structure determination were conducted. The NSS-COV-2 Mpro was cultured with $10 \mathrm{mM} \mathrm{N} 3$ for 30 minutes and crystallized by drip steam diffusion at $20^{\circ} \mathrm{C}$ using a 5 $\mathrm{mg} / \mathrm{ml}$ composite. The best crystals were cultured in a good buffer containing $0.1 \mathrm{M}$ MES $\mathrm{pH} \quad 6.0,2 \%$ polyethylene glycol (PEG) 6000, 3\% DMSO, 1 mM DTT. Low temperature protective solution containing $0.1 \mathrm{M}$ MES pH 6.0, 30\% PEG 400. [2]

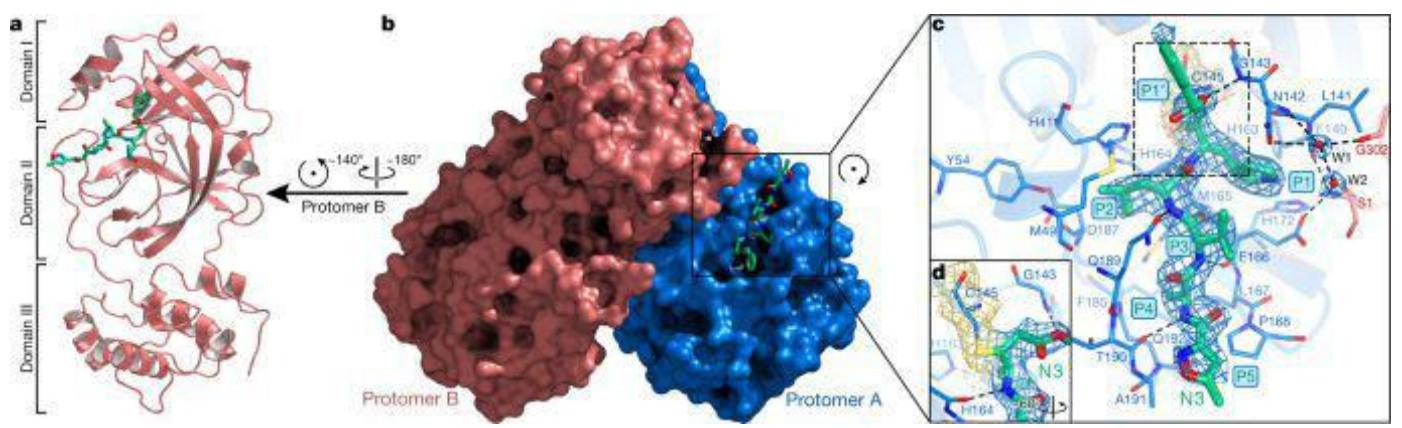

Figure 1. "Structure of Mpro from SARS-CoV-2 and discovery of its inhibitors" by Zhenming Jin, Xiaoyu Du, Yechun Xu et al. [3]

\section{Recombinant expression and purification of SARS-COV-2 Mpro based on PET-28A Mpro}

\subsection{Background}

Novel Coronavirus (SARS-COV-2) main protease (Mpro, NSP5) is a key protein in the virus replication cycle. Like a "small scissors", novel Coronavirus (SARS-COV-2) main protease (Mpro, NSP5) cuts a long chain protein encoded by the virus to form multiple proteins. Only after the small protein is assembled, can the replication of viral nucleic acid be started. Thus, Mpro is one of the most important drug targets of the novel Coronavirus. In this experiment, Mpro was expressed through in vitro recombinant expression, and the antiviral activity of the virtual screened compounds was tested in vitro. In this experiment, the Mpro gene was located on peT-28A vector, and the size of the recombinant protein was about $36 \mathrm{kDa}$. The principle of this experiment is the lactose operon based on coil. In the absence of lactose, LAC obstructs the binding of RNA polymerase to $\mathrm{P}$ sequence and inhibits transcriptional initiation.[4]

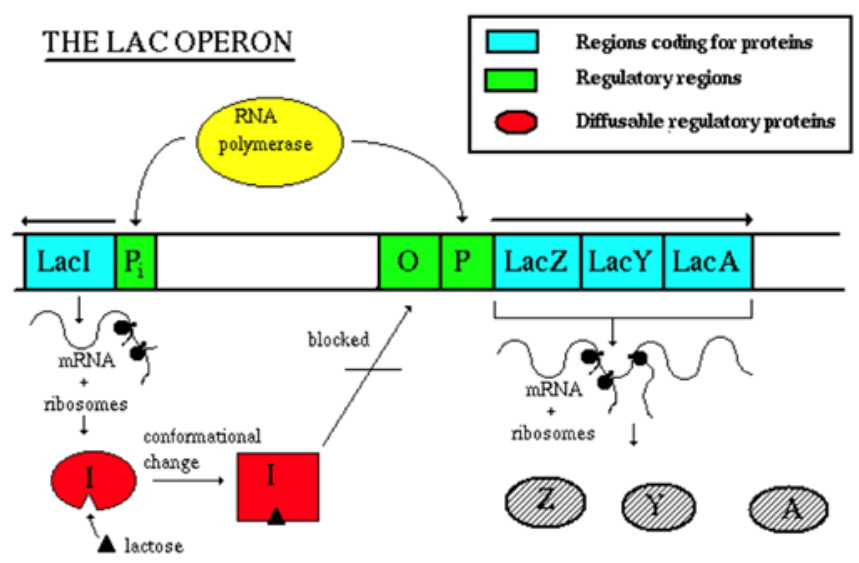

Figure 2. REGULATION OF GENE EXPRESSION by nau.edu[5]

\subsection{Method}

First prepare LB medium, 200ml per bottle. Kanamycin is needed in the sterilization process, a $50 \mathrm{mg} / \mathrm{ml}$ solution is needed, and then about $1 \mathrm{ml}$ of seeds are needed for night inoculation. According to the ratio of 1:500-1000, the concentration of kanamycin needs to be $50 \mathrm{mg} / \mathrm{ml}$, and it 
must be cultured at 37 degrees. Centrifuge at $5000 \mathrm{rpm}$ for 10 minutes to collect the bacteria and add to the culture medium. Store at $-20^{\circ} \mathrm{C}$. When using His buffer instead of regenerating protein, the change should be controlled at 1 $\mathrm{ml} / \mathrm{min}$. After replacing the regenerated protein, it needs to be placed for 4 seconds for temporary storage. Mark the deposit as recMpro. During this period, inducer IPTG was prepared at a concentration of $1 \mathrm{M}$ and 1-2 $\mathrm{ml}$. $200 \mathrm{~L}$ was assigned to each group. Can not filter and sterilize.Cell concentration was detected and induced expression. The cell concentration (OD600) was detected for the first time 2 hours after inoculation, and then the detection time was arranged according to the cell concentration. After the cell concentration reached 0.6-0.9, an inducer was added according to the final concentration of $0.5 \mathrm{~mm}$. After induction, the temperature was adjusted to about $25 \mathrm{oC}$ for overnight culture. About $1 \mathrm{ml}$ of the induced pre bacterial solution was collected and centrifuged at 5000 RPM for 2 min. The culture medium was abandoned and frozen at $20^{\circ} \mathrm{C}$. OD value was recorded to evaluate the number of cells. It is recommended to mark as Mpro-preind. The protein purification buffer was then prepared. Ultra-pure water $1 \mathrm{~L}, 20 \%$ ethanol, $0.5 \mathrm{~L}$ His buffer A (balance buffer) : $0.5 \mathrm{~L}, 20 \mathrm{~mm} \mathrm{Na} 2 \mathrm{hPO} 4.2 \mathrm{H} 2 \mathrm{O} 1.78 \mathrm{~g}, 500 \mathrm{~mm}$ $\mathrm{NaCl} 14.6 \mathrm{~g}, 20 \mathrm{~mm}$ Imidazole $1.02 \mathrm{~g}$. Adjust $\mathrm{pH}$ to 7.4 with $\mathrm{HCl}(6 \mathrm{M})$ and constant volume to $0.5 \mathrm{~L}$. Prepare His buffer B (eluent buffer) : 0.25L 20mm Na2HPO4.2H2O $0.89 \mathrm{~g}, 500 \mathrm{~mm} \mathrm{NaCl} 7.3 \mathrm{~g}$, and $500 \mathrm{~mm}$ Imidazole $8.5 \mathrm{~g}$. Adjust $\mathrm{pH}$ to 7.4 with $\mathrm{HCl}(6 \mathrm{M})$, and steady volume to $0.25 \mathrm{~L}$. The following figure shows an example of the structural basis for inhibiting the sarS-COV-2 main protease. The expressing cells were then collected. After centrifugation at $5000 \mathrm{RPM}$ for $10 \mathrm{~min}$, the bacteria were collected and the medium was discarded. Expressed cells were broken by ultrasound (or by pressure). The bacteria were taken out and about $10 \mathrm{ml}$ of his buffer $\mathrm{A}$ was added to fully suspend the cells. The cell suspension was placed in a suitable small beaker, and ultrasonic treatment was performed on the ice for $500 \mathrm{~W}$, and $2 \mathrm{~s}$ was broken for a total length of $15 \mathrm{~min}$. The supernatant was collected by centrifugation: the supernatant was centrifuged at 12,00020,000 RPM for 30-60 min. The supernatant was collected (precipitation was discarded) and filtered by a $0.45 \mathrm{~m}$ filter and placed on the ice. Centrifugation conditions depend on laboratory conditions. Finally, nickel column affinity purification was performed. Rinse 10 column volumes with His buffer A. The flow rate was controlled at about 1 $\mathrm{ml} / \mathrm{min}$. Sample on nickel column. The filtered cell supernatant was sampled into a nickel column at a flow rate of $1 \mathrm{ml} / \mathrm{min}$. Wash the nickel column after sample loading: wash the nickel column after sample loading with His buffer Solution A at A flow rate of $1 \mathrm{ml} / \mathrm{min}$. Recombinant protein elution: The recombinant protein was eluted with His buffer Solution B, the flow rate was 1 $\mathrm{ml} / \mathrm{min}$, and the recombinant protein was placed at $4 \mathrm{oC}$ for temporary preservation. Nickel column washing. Wash the column with His buffer B, His buffer A and water in turn. Nickel column preserved. Wash the column with 5 $\mathrm{ml} \mathrm{20 \%}$ ethanol. During the sample preparation, the cells were suspended with $100 \mathrm{~L}$ water and then added to the same-volume SDS solution with a final concentration of about $2 \%$ or directly added to the same-volume supernatant buffer. The solution was boiled for $10 \mathrm{~min}$ and centrifuged at $13000 \mathrm{RPM}$ for $10 \mathrm{~min}$. An appropriate amount of supernatant was added to the supernatant. The purified protein samples were added directly to the loading buffer. No cooking sample required.

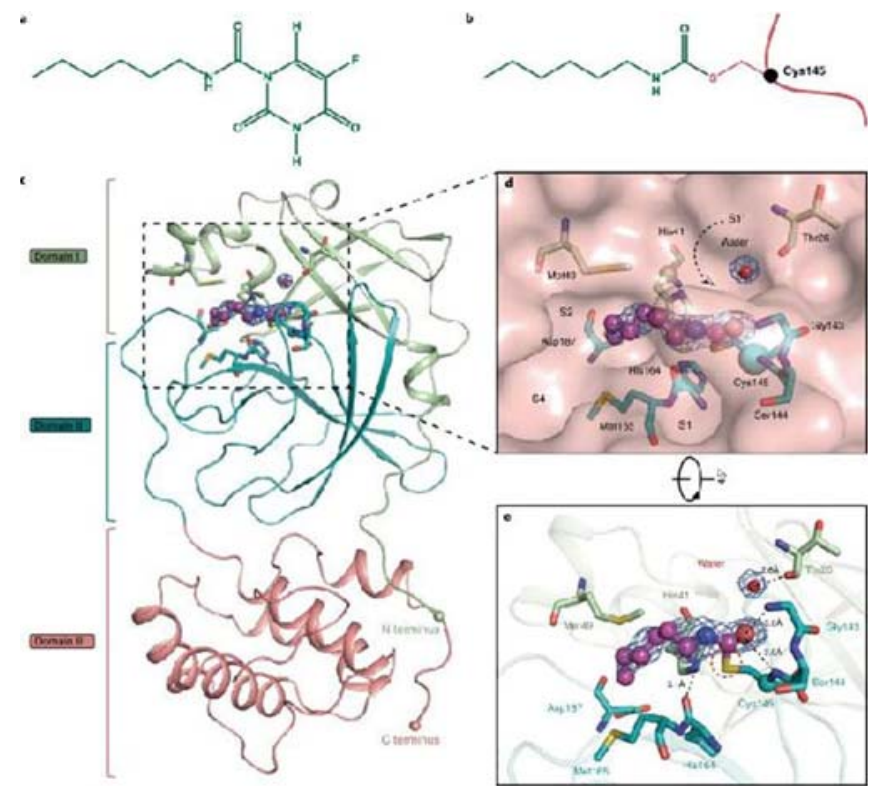

Figure 3. "Structural basis for the inhibition of SARS-CoV-2 main protease by antineoplastic drug carmofur" by Zhenming Jin, Yao Zhao, Yuan Sun et al. [6]

\section{Result}

The cell culture concentrations of LB medium 1 used in this experiment were $0.095,0.224,0.282,0.418,0.599$, 1.018; the experimental concentrations of LB medium 2 were $0.096,0.289,0.380,0.548,0.720, \quad 1.079$, respectively. Mpro group: Mpro 1 drug virtual screening concentration is 0.425 , experimental drug concentration is 
0.538; Mpro 2 drug virtual screening concentration is 0.538, and experimental molecular weight drug concentration is 0.441 . The concentration difference between the screening virtual screening and the experiment is about 0.1 .

\section{Conclusion}

During the experiment of LB medium, a series of problems were encountered. The needles have been infected with bacteria in the experiment. In the process of absorbing liquid, a small amount of air bubbles will be generated. This experiment is based on the lactose operon coil. There are also the following problems when using Mpro to prepare samples: 1 . The sample to be tested always floats on water during injection, because it contains a lipid film mainly made of paper, which is lighter than water, so it is easy to float; 2 . When purifying protein, The protein concentration is low, so there is no experimental zone. The reason may be that the protein is not completely transferred to the membrane, resulting in excessive protein loss. For samples that are always floating on water, a small amount $(10 \mu \mathrm{l})$ of SDS-PAGE can be injected into the colony so that the sample to be tested no longer floats and presents a layered state. For lower protein concentrations, an appropriate amount of protein can be added.

\section{References}

1. Fei Liu, "Structure of the main protease $\mathrm{M} \sim(\mathrm{PRO})(3 \mathrm{CL} \sim(\mathrm{PRO}))$ of coronavirus: The basis of designing anti-SARS drugs", CNKI: SUN: JCYL. 0.2003-03-026, 2003, Accessed Date: 11/26/2020.

2. Jin, Z., Du, X., Xu, Y. et al. "Structure of Mpro from SARS-CoV-2 and discovery of its inhibitors." Nature 582, 289-293 (2020). //doi.org/10.1038/s41586-0202223-y, 09 Apr 2020, Accessed Date: 11/26/2020.

3. Jin, Z., Du, X., Xu, Y. et al. "Structure of Mpro from SARS-CoV-2 and discovery of its inhibitors." Nature 582, 289-293 (2020). //doi.org/10.1038/s41586-0202223-y, 09 Apr 2020, Accessed Date: 11/26/2020.

4. Jin, Z., Du, X., Xu, Y. et al. "Structure of Mpro from SARS-CoV-2 and discovery of its inhibitors." Nature 582, 289-293 (2020). //doi.org/10.1038/s41586-0202223-y, 09 Apr 2020, Accessed Date: 11/26/2020.

5. Kneller, D.W., Phillips, G., O’Neill, H.M. et al. "Structural plasticity of SARS-CoV-2 3CL Mpro active site cavity revealed by room temperature X-ray crystallography”. Nat Commun 11, 3202 (2020). //doi.org/10.1038/s41467-020-16954-7, 24 Jun 2020, Accessed Date: 11/26/2020.

6. Griffiths AJF, Gelbart WM, Miller JH, et al. "Modern Genetic Analysis." www.ncbi.nlm.nih.gov/books/NBK21402/,Accessed Date: $11 / 26 / 2020$.

7. nau.edu, "REGULATION OF GENE EXPRESSION."

www2.nau.edu/ fpm/bio205/lacoper.htm, Accessed
Date: $11 / 26 / 2020$.

8. Jin, Z., Zhao, Y., Sun, Y. et al."Structural basis for the inhibition of SARS-CoV-2 main protease by antineoplastic drug carmofur. Nat Struct Mol Biol 27, 529-532 (2020). " , //doi.org/10.1038/s41594-0200440-6, 07 May 2020, Accessed Date: 11/26/2020. 